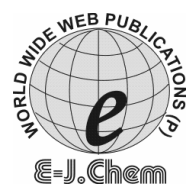

http://www.e-journals.net
ISSN: 0973-4945; CODEN ECJHAO

E-Journal of Chemistry 2009, 6(1), 281-288

\title{
Synthesis, Characterization and Chelating Properties of Benzimidazole-Salicylic Acid Combined Molecule
}

\author{
KAMLESH V. PATEL and ARUN SINGH* \\ Department of Chemistry, \\ Govt.Geetanjali P.G. Girls College, Bhopal, India. \\ kammo31@yahoo.co.in
}

Received 22 May 2008; Accepted 20 July 2008

\begin{abstract}
Aminomethylation (i.e. Mannich reaction) of benzimidazole was carried out by treating benzimidalzole with formaldehyde and 4-aminosalicylic acid. The resultant compound was designated as 1-(4-carboxy-3-hydroxyphenyl aminomethyl) benzimidazole (BI-SA). The transition metal complexes of $\mathrm{Cu}^{2+}$, $\mathrm{Co}^{2+}, \mathrm{Ni}^{2+}, \mathrm{Mn}^{2+}, \mathrm{Zn}^{2+}$ and $\mathrm{Fe}^{3+}$ of BI-SA have been prepared and characterized by elemental analyses, spectral studies, magnetic moment determination, molar conductivity measurement and microbicidal activity.
\end{abstract}

Keywords: 3(H) Benzimidazole, 4-Aminosalicylic acid, Metal chelates, Spectral studies, Magnetic moment, Antibacterial and antifungal activity.

\section{Introduction}

Benzimidazoles belonging to the fused heterocyclic system prepared from amino acids are associated with diverse pharmaceutical activities such as antibacterial ${ }^{1}$, insecticidal ${ }^{2}$, fungicidal $^{3}$, antimicrobial ${ }^{4}$, antagonist ${ }^{5}$, anthelmintic ${ }^{6-8}$ and anti-inflamonatary ${ }^{9}$ etc. Recently the benzimidazole derivative has been reported with remarkable antimicrobial activity ${ }^{10}$. The Mannich reaction of benzimidazole derivative with 4-aminosalicylic acid has not been reported so far, though 4-amino salicylic acid is excellent anti T.B agent. Thus this may afford good chelating ligand with better microbicidal activity. Hence it was thought interesting to prepare the ligand having benzimidazole-salicylic acid moieties. Thus the present communication comprises the studies on benzimidazolesalicylic acid combined molecule and its metal chelates. The research work is illustrated in Scheme 1. 


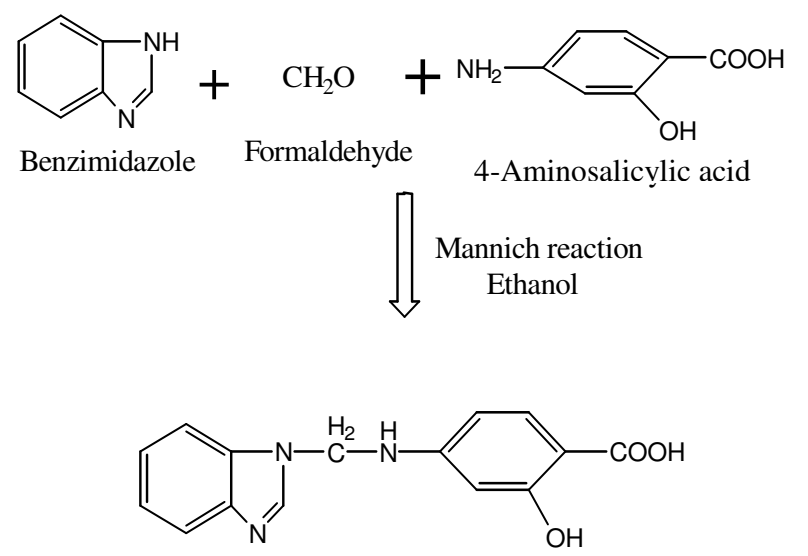

1-(4-Carboxy-3-hydroxy phenylaminomethylene)benzimidazole (BI-SA)

\title{
Experimental
}

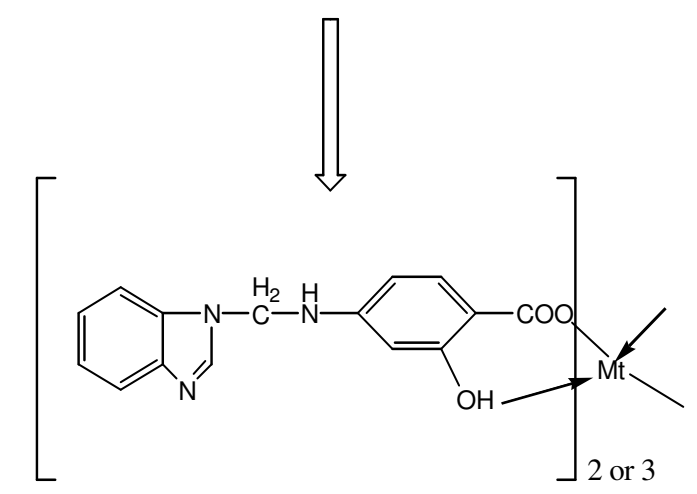

\author{
BI-SA Metal Chelates \\ Where Mt: $\mathrm{Cu}^{2+}, \mathrm{NI}^{2+}, \mathrm{Zn}^{2+}, \mathrm{Mn}^{2+}, \mathrm{Fe}^{3+}$
}

Benzimidazole was prepared by method reported in literature ${ }^{11} \cdot p$-Amino salicylic acid (PAS) (i.e. 4-Aminosalicylic acid) was obtained from local dealer. All other chemicals used were of analytical grade.

\section{Synthesis of 1-(4-carboxy 3-hydroxy phenyl aminomethyl) benzimidazole}

Formation BI-SA

A mixture of benzimidazole (BI) $(0.02$ mole $)$, formaldehyde $(0.02$ mole $)$ and 4-aminosalicylic acid (PAS) $(0.02$ mole) in ethanol $(70 \mathrm{~mL})$ was heated under reflux for $4 \mathrm{~h}$. Subsequently ethanol was distilled off and the lump mass obtained. It was triturated with petroleum ether $\left(40-60^{\circ} \mathrm{C}\right)$. The solid designated as BI-SA was isolated and dried in air. Yield was $70 \%$. The m.p. was $181-82^{\circ} \mathrm{C}$ (uncorrected). 
Elemental Analysis: $\mathrm{C}_{15} \mathrm{H}_{13} \mathrm{O}_{3} \mathrm{~N}_{3}(283)$

$\mathrm{H} \%$

Calculated: $\quad 63.60$

4.59

14.84

Found : 63.50

4.50

14.80

Acid Value

Theoretical: $197.8 \mathrm{mg} \mathrm{KOH} / 1 \mathrm{~g}$. Sample. Found: $195 \mathrm{KOH} / \mathrm{g}$ Sample.

IR Features

$$
1480-1520 \mathrm{~cm}^{-1} \text {. }
$$

Benzimidazole

$3030,1500,1600 \mathrm{~cm}^{-1}$ Aromatic.

$1680 \mathrm{~cm}^{-1}$

$\mathrm{CO}$ of $\mathrm{COOH}$

$3200-3600 \mathrm{~cm}^{-1}$

$\mathrm{OH}$

$3400 \mathrm{~cm}^{-1}$

Sec.NH

$2850,2920 \mathrm{~cm}^{-1}$

$\mathrm{CH}_{2}$

NMR

$\delta \mathrm{ppm}$

(DMSO)

$7.2-7.6(8 \mathrm{H})$
$2.56(2 \mathrm{H})$
$10.1(1 \mathrm{H})$
$3.9(1 \mathrm{H})$
$2.8(1 \mathrm{H})$

$\begin{array}{ll}\text { Multiplet } & \text { Aromatic } \\ \text { Singlet } & \mathrm{CH}_{2} \\ \text { Singlet } & (\mathrm{COOH}) \\ \text { Singlet } & (\mathrm{OH}) \\ \text { Singlet } & (\mathrm{NH})\end{array}$

Synthesis of metal chelates of BI-SA

The $\mathrm{Cu}^{2+}, \mathrm{Co}^{2+}, \mathrm{Ni}^{2+}, \mathrm{Mn}^{2+}, \mathrm{Zn}^{2+}$, and $\mathrm{Fe}^{3+}$ metal ion chelates of BI-SA have been prepared in a similar manner. The procedure is as follow.

To a solution of BI-SA (31.3 g 0.1 mole) in ethanol-acetone $(1: 1 \mathrm{v} / \mathrm{v})$ mixture $(150 \mathrm{~mL})$, $0.1 \mathrm{~N} \mathrm{KOH}$ solution was added drop wise with stirring. The pasty precipitates were obtained at neutral $\mathrm{pH}$. These were dissolved by addition of water up to clear solution. It was diluted to $250 \mathrm{~mL}$ by water and was known as stock solution. $25 \mathrm{~mL}$ of the stock solution (which contains 0.01 mole BI-SA) was added drop wise to the solution of metal salt ( 0.005 mole for divalent metal ions and 0.0033 mole for $\mathrm{Fe}^{3+}$ ion) in water at room temperature. Sodium acetate or ammonia was added up to complete precipitation. The precipitates were digested on water bath at $80^{\circ} \mathrm{C}$ for $2 \mathrm{~h}$. The digested precipitates of chelates were filtered washed with water and air dried. It was amorphous powder. Yield was almost quantitative. The details are given in Table 1.

\section{Measurements}

The elemental analysis for $\mathrm{C}, \mathrm{H}$ and $\mathrm{N}$ were carried out on elemental analyzer TF-EA.1101 (Italy). IR spectra of BI-SA and its metal complexes were scanned on a Nicolet 760 FTIR spectrophotometer in $\mathrm{KBr}$. The NMR spectrum of BI-SA was scanned on Brucker NMR spectrophotometer using DMSO solvent. The metal content of the metal chelate were performed by decomposing a weighed amount of each metal complexes followed by EDTA titration as reported in literature ${ }^{12}$. Magnetic susceptibility measurement of the entire metal complex was carried out at room temperature by the Gouy mehod. Mercury tetrathiocynatocobalate(II) $\mathrm{Hg}\left[\mathrm{Co}(\mathrm{NCS})_{4}\right]$ was used as a calibrant. The diffused reflectance spectra of solid metal complex were recorded on a Backman DK Spectrophotometer with a solid reflectance attachment, $\mathrm{MgO}$ was employed as the reflectance compound. The electrical conductivity of all the complexes was measure in acetonitrile at $10^{-3} \mathrm{M}$ concentration. 
Table 1. Analytical data of the metal chelates of $\mathrm{HL}_{1}$ (i.e. BI-SA)

\begin{tabular}{|c|c|c|c|c|c|c|c|c|c|c|c|}
\hline \multirow{3}{*}{ Compound } & \multirow{3}{*}{$\begin{array}{l}\text { Empirical } \\
\text { Formula }\end{array}$} & \multirow{3}{*}{$\begin{array}{l}\text { Mol. Calc. } \\
\text { g/mol }\end{array}$} & \multirow{3}{*}{$\begin{array}{c}\text { Yield } \\
\%\end{array}$} & \multicolumn{8}{|c|}{ Elemental Analysis } \\
\hline & & & & \multicolumn{2}{|c|}{$\mathrm{C} \%$} & \multicolumn{2}{|c|}{$\mathrm{H} \%$} & \multicolumn{2}{|c|}{$\mathrm{N} \%$} & \multicolumn{2}{|c|}{ M\% } \\
\hline & & & & Calc. & Found & Calc. & Found & Calc. & Found & Calc. & Found \\
\hline HL (BI-SA) & $\mathrm{C}_{15} \mathrm{H}_{13} \mathrm{O}_{3} \mathrm{~N}_{3}$ & 283 & 55 & 63.60 & 63.6 & 4.59 & 4.5 & 14.8 & 14.8 & -- & -- \\
\hline$(\mathrm{L})_{2} \mathrm{Cu}^{2+}$ & $\mathrm{C}_{30} \mathrm{H}_{24} \mathrm{~N}_{6} \mathrm{O}_{6} \mathrm{Cu}^{2+} 2 \mathrm{H}_{2} \mathrm{O}$ & 663.54 & 57 & 54.25 & 54.2 & 3.61 & 3.5 & 12.6 & 12.6 & 9.57 & 9.4 \\
\hline$(\mathrm{L})_{2} \mathrm{Co}^{2+}$ & $\mathrm{C}_{30} \mathrm{H}_{24} \mathrm{~N}_{6} \mathrm{O}_{6} \mathrm{Co}^{2+} 2 \mathrm{H}_{2} \mathrm{O}$ & 658.93 & 58 & 54.63 & 54.6 & 3.64 & 3.5 & 12.7 & 12.7 & 8.94 & 9.9 \\
\hline$(\mathrm{L})_{2} \mathrm{Ni}^{2+}$ & $\mathrm{C}_{30} \mathrm{H}_{24} \mathrm{~N}_{6} \mathrm{O}_{6} \mathrm{Ni}^{2+} 2 \mathrm{H}_{2} \mathrm{O}$ & 658.69 & 50 & 54.65 & 54.6 & 3.64 & 3.5 & 12.7 & 12.7 & 8.91 & 8.9 \\
\hline$(\mathrm{L})_{2} \mathrm{Mn}^{2+}$ & $\mathrm{C}_{30} \mathrm{H}_{24} \mathrm{~N}_{6} \mathrm{O}_{6} \mathrm{Mn}^{2+} 2 \mathrm{H}_{2} \mathrm{O}$ & 654.93 & 60 & 54.96 & 54.9 & 3.66 & 3.6 & 12.8 & 12.8 & 8.38 & 8.3 \\
\hline$(\mathrm{L})_{2} \mathrm{Zn}^{2+}$ & $\mathrm{C}_{30} \mathrm{H}_{24} \mathrm{~N}_{6} \mathrm{O}_{6} \mathrm{Zn}^{2+} 2 \mathrm{H}_{2} \mathrm{O}$ & 665.38 & 60 & 54.10 & 54.0 & 3.60 & 3.5 & 12.6 & 12.6 & 9.82 & 8.8 \\
\hline$(\mathrm{L})_{2} \mathrm{Fe}^{3+}$ & $\mathrm{C}_{45} \mathrm{H}_{36} \mathrm{~N}_{9} \mathrm{O}_{9} \mathrm{Fe}^{3+} 3 \mathrm{H}_{2} \mathrm{O}$ & 955.84 & 55 & 56.49 & 56.4 & 3.76 & 3.7 & 13.1 & 13.1 & 5.82 & 5.8 \\
\hline
\end{tabular}




\section{Antifungal activity}

The fungicidal activity of all the compounds was studied at $1000 \mathrm{ppm}$ concentration in vitro plant pathogenic organisms listed in Table 3. The antifungal activities of all the samples were measured by cup plate method ${ }^{13}$. Each of the plant pathogenic strains on potato dextrose agar (PDA) medium. Such a PDA medium contained potato $200 \mathrm{~g}$, dextrose $20 \mathrm{~g}$, agar $20 \mathrm{~g}$ and water 1 liter. 5 days old cultures were employed. The compounds to be tested were suspended $(1000 \mathrm{ppm})$ in a PDA medium and autoclaved at $120^{\circ} \mathrm{C}$ for $15 \mathrm{~min}$ at 15 atm pressure. These medium were poured into sterile Petri plate and the organisms were inoculated after cooling the Petri plate. The percentage inhabitation for fungi was calculated after 5 days using the formula given below.

$$
\begin{gathered}
\text { Percentage of inhibition }=\frac{100(\mathrm{X}-\mathrm{Y})}{\mathrm{X}} \\
\text { Where, X: Area of colony in control plate } \\
\text { Y: Area of colony in test plate }
\end{gathered}
$$

The fungicidal activity all compound are shown in Table 3

\section{Results and Discussion}

The parent ligand BI-SA was an amorphous brown powder, soluble in various solvents like dioxane, DMSO and DMF. The results of elemental analysis of the ligand are reported in experimental part. They are consistent with the predicted structure as shown in Scheme 1.

Examination of IR spectrum (not shown) of BI-SA reveals that broad band of phenolic hydroxyl stretching is observed at $3200-3600 \mathrm{~cm}^{-1}$ as well as additional absorption bands at 3030,1500 and 1600 are characteristics of the salicylic acid ${ }^{10,11}$. The strong bands at 1680 for $\mathrm{C}=\mathrm{O}$ and band at 3400 for sec. NH. The NMR data (shown in experimental part) also confirm the structure of BI-SA.

The metal chelate of BI-SA with ions $\mathrm{Cu}^{2+}, \mathrm{Co}^{2+}, \mathrm{Ni}^{2+}, \mathrm{Mn}^{2+}, \mathrm{Zn}^{2+}, \mathrm{Fe}^{3+}$ vary in colours. On the basis of the proposed structure as shown in Scheme 1, the molecular formula of the BI-SA ligand is $\mathrm{C}_{15} \mathrm{H}_{13} \mathrm{O}_{3} \mathrm{~N}_{3}$ which upon complexion coordinates with one central metal atom at four coordination sites and with two water molecules. Therefore the general molecular formula of the resulting metal chelate is $\left[\begin{array}{llll}\mathrm{C}_{15} & \mathrm{H}_{12} & \mathrm{O}_{3} & \mathrm{~N}_{3}\end{array}\right]_{2} \mathrm{M} .2 \mathrm{H}_{2} \mathrm{O}$ for divalent metal ions. This has been confirmed by results of elemental analysis reported in Table 1 . The data are in agreement with the calculated values.

Inspection of the IR Spectra (not shown) of metal chelates reveals that all the spectra are identical in all respects. The comparison of IR spectrum of the parent ligand BI-SA with that of its each metal chelates has revealed certain characteristics differences.

One of the significant differences to be expected between the IR spectrum of the parent ligand and its metal chelates is the presence of more broadened bands in the region of 3200$3600 \mathrm{~cm}^{-1}$ for the metal chelates as the oxygen of the $\mathrm{O}-\mathrm{H}$ group of the ligands forms a coordination bond with the metal ions ${ }^{13-15}$. This is explained by the fact that water molecule might have strongly absorbed to the metal chelates samples during their formation. Another noticeable difference is that the bands due to the $\mathrm{COO}^{-}$anion at $1600 \mathrm{~cm}^{-1}$ in the IR spectrum of the each metal chelates. The band at $1400 \mathrm{~cm}^{-1}$ in the IR Spectrum of HL assigned to inplane $\mathrm{OH}$ determination ${ }^{13-15}$ is shifted towards higher frequency in the spectra of confirmed by a week bands at $1105 \mathrm{~cm}^{-1}$ corresponding to C-O-M starching ${ }^{13-15}$. Thus all of these characteristics features of the IR studies suggested the structure of the metal chelates as shown in scheme. 
Examination of data of the metal content in each compound revealed a 1:2 metal: ligand (M: L) stoichiometry in all of the chelate of divalent metal ions and 1:3 metal: ligand stoichiometry for $\mathrm{Fe}^{3+}$.

Magnetic moment $\left(\mu_{\text {eff }}\right)$ of each of the metal chelates is given in Table 2. Examination of these data reveals that all chelates other than that of $\mathrm{Zn}^{2+}$, are para magnetic while those of $\mathrm{Zn}^{2+}$ are diamagnetic.

Table 2. Magnetic moment and reflectance spectral data of metal chelates of BI - SA ligand

\begin{tabular}{|c|c|c|c|c|}
\hline $\begin{array}{l}\text { Metal } \\
\text { chelate }\end{array}$ & $\begin{array}{l}\text { Magnetic Moment } \\
\mu_{\text {eff }} \text { (B.M.) }\end{array}$ & 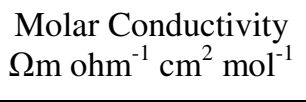 & $\begin{array}{l}\text { Absorption } \\
\text { band, } \mathrm{cm}^{-1}\end{array}$ & Transitions \\
\hline $\mathrm{Cu}-\mathrm{HL}$ & 1.94 & 37.3 & 2268515860 & C. $\mathrm{T}^{2} \mathrm{~T} \rightarrow{ }^{2} \mathrm{~T}_{2} \mathrm{~g}$ \\
\hline $\mathrm{Ni}-\mathrm{HL}$ & 3.85 & 36.0 & 1469022983 & $\begin{array}{l}3 \mathrm{~A} 2 \mathrm{~g} \rightarrow 3 \mathrm{~T}_{1} \mathrm{~g}(\mathrm{p}) \\
3 \mathrm{~A} 1 \mathrm{~g} \rightarrow 3 \mathrm{~T}_{1} \mathrm{~g}(\mathrm{~F})\end{array}$ \\
\hline Co-HL & 4.52 & 35.3 & 1537522715 & $\begin{array}{l}4 \mathrm{~T} 1 \mathrm{~g}(\mathrm{~F}) \rightarrow 4 \mathrm{~T}_{2} \mathrm{~g}(\mathrm{~F}) \\
4 \mathrm{~T} 1 \mathrm{~g}(\mathrm{~F}) \rightarrow 3 \mathrm{~A} 2 \mathrm{~g}\end{array}$ \\
\hline Mn-HL & 5.10 & 37.6 & $\begin{array}{c}1537417649 \\
22960\end{array}$ & $\begin{array}{l}6 \mathrm{~A} 1 \mathrm{~g} \rightarrow 4 \mathrm{~T}_{1} \mathrm{~g}(4 \mathrm{Eg}) \\
6 \mathrm{~A} 1 \mathrm{~g} \rightarrow 4 \mathrm{~T} 2 \mathrm{~g}(4 \mathrm{G}) \\
6 \mathrm{~A} 1 \mathrm{~g} \rightarrow 4 \mathrm{~T}_{1} \mathrm{~g}(4 \mathrm{G})\end{array}$ \\
\hline $\mathrm{Fe}-\mathrm{HL}$ & 5.86 & 39.1 & 1901223001 & $\begin{array}{l}6 \mathrm{~A} 1 \rightarrow 4 \mathrm{~T}_{2} \mathrm{~g}(4 \mathrm{G}) \\
6 \mathrm{~A} 1 \mathrm{~g} \rightarrow 4 \mathrm{~T}_{1} \mathrm{~g}(4 \mathrm{G}) \\
\end{array}$ \\
\hline
\end{tabular}

$\mathrm{Zn}^{2+}$ Diamagnetic in Nature.

The diffuse electronic spectrum of the $\left[\mathrm{Cu} \mathrm{HL}\left(\mathrm{H}_{2} \mathrm{O}\right)_{2}\right]$ metal complex shows broad bands at 15860 and $22685 \mathrm{~cm}^{-1}$ due to the ${ }^{2} \mathrm{~T} \rightarrow{ }^{2} \mathrm{~T}_{2} \mathrm{~g}$ transition and charge transfer, respectively suggesting a distorted octahedral structure ${ }^{16-18}$ for the $\left[\mathrm{Cu} \mathrm{HL}\left(\mathrm{H}_{2} \mathrm{O}\right)_{2}\right.$ ] complex. Which is further confirmed by the higher value of $\mu_{\text {eff }}$ of the $\left[\mathrm{Cu} H L\left(\mathrm{H}_{2} \mathrm{O}\right)_{2]}\right.$ complex. The $\left[\mathrm{Ni} \mathrm{HL}\left(\mathrm{H}_{2} \mathrm{O}\right)_{2}\right]$ and $\left[\mathrm{Cu} \mathrm{HL}\left(\mathrm{H}_{2} \mathrm{O}\right)_{2}\right]$ complex gave two absorption bands respectively at 15601,22983 , and $15375,22715, \mathrm{~cm}^{-1}$ corresponding to ${ }^{4} \mathrm{~T}_{1} \mathrm{~g} \rightarrow{ }^{2} \mathrm{~T}_{1} \mathrm{~g}$ and ${ }^{4} \mathrm{~T}_{1} \mathrm{~g}$ (p) transitions. Thus absorption bands at the diffuse, reflectance spectra and the value of the magnetic moments $\mu_{\text {eff }}$ indicate and octahedral configuration for the $\left[\mathrm{NiHL}\left(\mathrm{H}_{2} \mathrm{O}\right)_{2}\right]$ and $\left[\mathrm{Cu} \mathrm{HL}\left(\mathrm{H}_{2} \mathrm{O}\right)_{2}\right]$ complex.

The spectra of [Mn HL $\left(\mathrm{H}_{2} \mathrm{O}\right)_{2}$ ] shows weak bands at 15374, 17649, and $22960 \mathrm{~cm}^{-1}$ assigned to the transitions ${ }^{6} \mathrm{~A}_{1 \mathrm{~g}} \rightarrow{ }^{4} \mathrm{~T}_{1 \mathrm{~g}}(4 \mathrm{G}),{ }^{6} \mathrm{~A}_{1 \mathrm{~g}} \rightarrow{ }^{4} \mathrm{~T}_{2 \mathrm{~g}}(4 \mathrm{G})$ and ${ }^{6} \mathrm{~A}_{1 \mathrm{~g}}(\mathrm{~F}) \rightarrow{ }^{4} \mathrm{~T}_{1} \mathrm{~g}$, respectively suggesting an octahedral structure for the $\left[\mathrm{Mn} \mathrm{HL}\left(\mathrm{H}_{2} \mathrm{O}\right)_{2}\right]$ chelate. The spectrum of $\mathrm{Fe}^{3+}$ complex has not been adequately characterized. The spectrum comprised the band ground $19012 \mathrm{~cm}^{-1}$ and other weak band ground $23001 \mathrm{~cm}^{-1}$. The latter has not very long tail. These may have the transition ${ }^{6} \mathrm{~A}_{1 \mathrm{~g}} \rightarrow{ }^{4} \mathrm{~T}_{2 \mathrm{~g}}(4 \mathrm{G})$ and ${ }^{6} \mathrm{~A}_{1} \rightarrow{ }^{4} \mathrm{~T}_{1}(4 \mathrm{G})$. The high intensities of the bands suggests that they might be charge transfer in origin $\mu_{\text {eff }}$ is found to be lower than normal range. In the absence of low temperature moments it is difficult to give any significance. As the spectrum of the [ $\mathrm{Zn} \mathrm{HL}\left(\mathrm{H}_{2} \mathrm{O}\right)_{2}$ ] polymer is not well resolved, it is not interpreted but it is $\mu_{\text {eff }}$ value shows that it is diamagnetic as expected.

Conductivities of all the complexes were measured in acetonitrile solvent and all the complexes were found to be electrolytic ${ }^{19}$ in nature of 1:2 type and molar conductivity values are in the range of 25.3-39.1 $\mathrm{Ohm}^{-1} \mathrm{~cm}^{-1}$.

The antifungal activity of all the compounds measured for various plant pathogens. Inspection of the result shown in Table 3 indicates that all compounds are good toxic for 
fungi. Out of all the compounds copper chelates is more toxic than other. These compounds almost inhibit the fungi about $70 \%$. Hence produced metal chelates can be employed as garden fungicides. Further work in the direction is in progress.

Table 3. Antifungal activity of ligand $\mathrm{HL}_{1}$ and its metal chelates.

\begin{tabular}{|c|c|c|c|c|c|c|c|}
\hline \multirow[t]{2}{*}{ Sample } & \multicolumn{7}{|c|}{ Zone of inhibition of fungus at $1000 \mathrm{ppm}, \%$} \\
\hline & $\mathrm{PE}$ & BT & $\mathrm{N}$ & $\mathrm{T}$ & RN & AN & TL \\
\hline (HL1)-Mn & 64 & 71 & 70 & 71 & 70 & 71 & 70 \\
\hline (HL1)-Co ${ }^{2+}$ & 73 & 72 & 73 & 75 & 73 & 75 & 71 \\
\hline (HL1)- $-\mathrm{Ni}^{2+}$ & 70 & 77 & 75 & 79 & 74 & 71 & 74 \\
\hline (HL1)- $\mathrm{Cu}^{2+}$ & 73 & 78 & 77 & 82 & 75 & 73 & 76 \\
\hline (HL1)- $\mathrm{Fe}^{3+}$ & 71 & 71 & 74 & 76 & 78 & 72 & 75 \\
\hline (HL1)- $\mathrm{Zn}^{2+}$ & 68 & 77 & 71 & 77 & 71 & 70 & 71 \\
\hline (HL1)-UO ${ }^{2+}$ & 65 & 68 & 74 & 72 & 72 & 72 & 65 \\
\hline HL1 & 61 & 61 & 62 & 64 & 65 & 60 & 60 \\
\hline
\end{tabular}

$\mathrm{PE}=$ Penicillium expansum $; \mathrm{BT}=$ Botrydepladia thiobromine; $\mathrm{N}=$ Nigrospra sp.;

$\mathrm{T}=$ Trichothesium sp.; $\mathrm{RN}=$ Rhizopus nigricans; $\mathrm{AN}=$ Aspergillus niger.;

$\mathrm{TL}=$ Trichoderna lignorum

\section{Acknowledgments}

The author thanks to Dr. (Mrs.) Nayantara Pathak Principal, Govt. Geetanjali P.G. Collage, Bhopal for providing necessary research facilities. The author also thanks to Dr. M.V.Hathi Science Collage, Palanpur, Gujarat for permission of extension of his work.

\section{References}

1. Kiyoshi O, Japan Kokai, 10, 024; Chem Abstr. 1978, 88, 3318g.

2. Werner D, Walfgang B, Ingebarg H, Hans S and Willum B, Ger Often. 2612315, Chem. Abstr, 1978,. 88, ,79698.

3. Hans W, Gnenter D and Paul H, Ger. (East) 127636. Chem Abstr. 88, 136680 w.

4. Pegfei X, Ximping Y, Shaozn W and Ziyl Z, Indian J Chem., 1998, 127, 3713.

5. Neustadt B R and Smith E M, PCT Int. Appl. W00032578, (Chem Abstr, 2003, 133, 309589).

6 Puratchikody A, Sivagothi V, Zaswanth A, Rutkmani and K, Nalul M, Indian J Heterocycl Chem., 2001, 241.

7. Pandey V K and Raj N, Curr Sci., 1980, 53, 256.

8. Sengupta A K, Gupta A A and Chandra V, Indian Drug, 1985, 18, 233.

9. Evans D, Hicks T A, Willamsan W R N, Aavidsian W, Meacock S C R and Kitchen E A, Chem Abstr., 1986, 125, 2476894.

10. Bhatt A K, Shah P K, Karadia H G and Patel H D, Orient J Chem., 2003, 19, 643.

11. Vogel A I, Textbook of Quantitative Chemical Analysis, ELBS $5^{\text {th }}$ Ed., London, 1996.

12. Baily W R and Scott E G, Diagnostic Microbiology, The C V Moshy Co. St. Lovis, 1966, 257.

13. Silverstein R M, Spectrometric Identification of organic compounds, $5^{\text {th }}$ Ed., John Wiley, 1991.

14. Kemp W, Organic Spectroscopy, ELBS, (Macmillan’ UK), 1998. 
15. Nakamoto K, Infared Spectra of Inorganic and Co-ordination Compound, Wiley NY, 1970,

16. ABP Lever, Inorganic Electronic Spectroscopy, Elseviv, NY, 1968.

17. Figgis B N, Introduction to Ligands Field, Wiley Estern Ltd., NY, 1976.

18. Carlin R N and Van Dryneveldt A J, Magnetic properties of Transition Metal Compound, Springe- Berlag, NY, 1997.

19. Kettle F A, Coordination Compounds, Thomas Nelson \& Sons, 1975. 


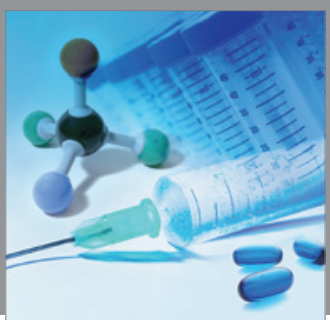

International Journal of

Medicinal Chemistry

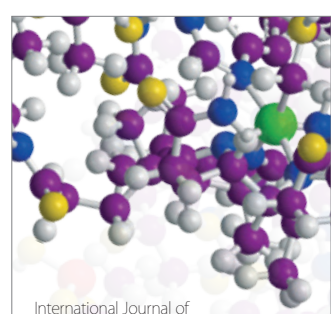

Carbohydrate Chemistry

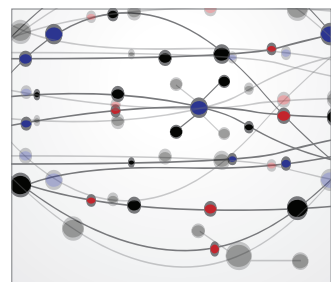

The Scientific World Journal
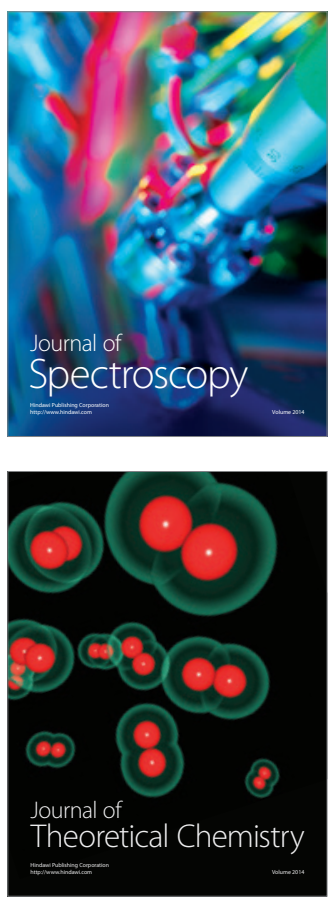
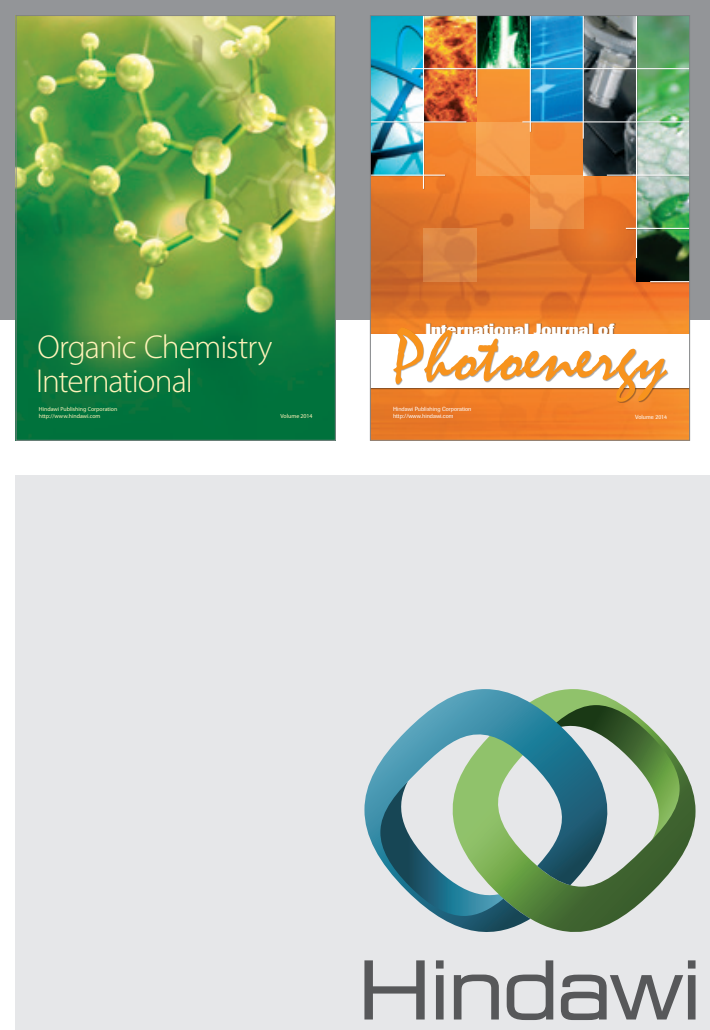

Submit your manuscripts at

http://www.hindawi.com
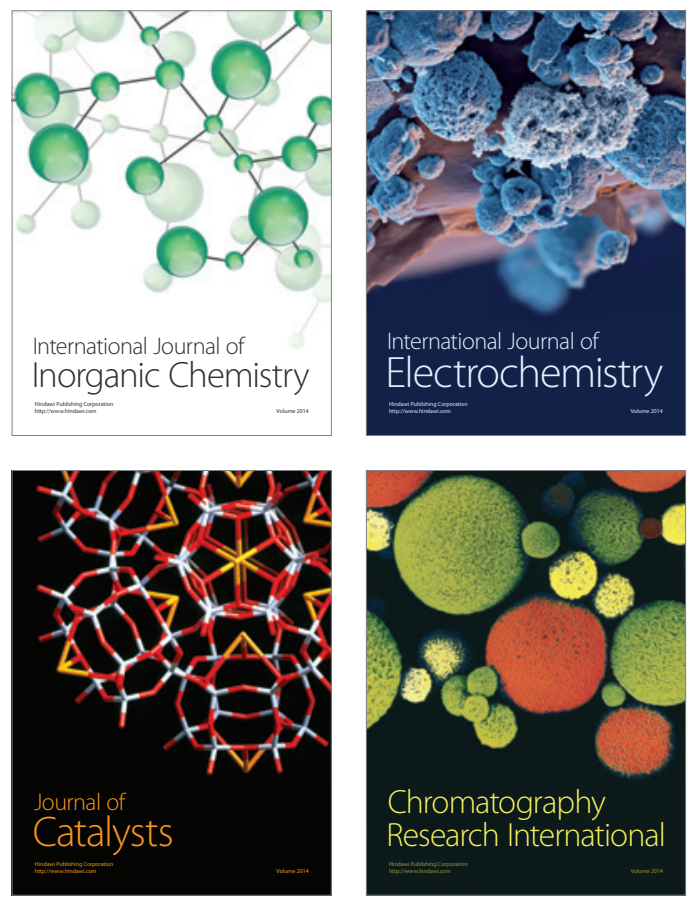
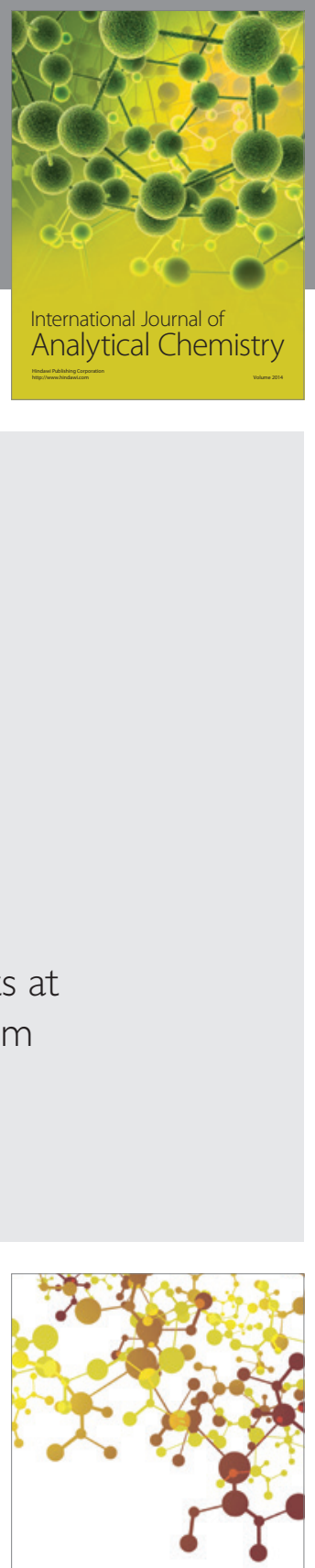

Journal of

Applied Chemistry
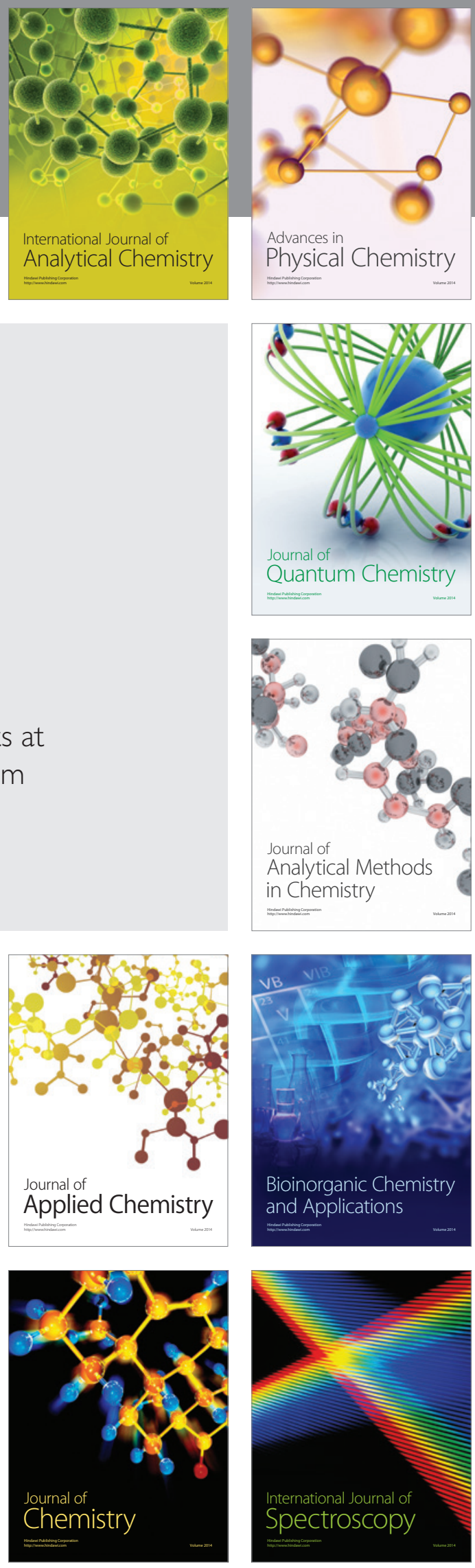